\title{
Growth and cropping of two cultivars of peach and nectarine in the conditions of the Sandomierska Plateau
}

\author{
Stanistaw Wociór \\ Department of Seed Science and Horticultural Nursery \\ University of Life Sciences in Lublin \\ Leszczyńskiego 58, 20-068 Lublin, Poland \\ e-mail: stanislaw.wocior@up.lublin.pl
}

Key words: efficiercy, flowering, spring frost, trees, yielding

\begin{abstract}
In this experiment, the growth of peach and nectarine trees was determined to be related to the cultivar. 'Inka' peach trees grew weaker than 'Harbinger' trees. The 'John Rivers' nectarine was characterized by stronger growth than the 'Harko'. The amount of crops produced by the trees was related to the cultivar and the meteorological conditions during winter and spring. 'Inka' produced higher yields and bigger fruits as compared to 'Harbinger'. The 'Harko' cultivar provided significantly higher yields than the 'John Rivers' only in 2006. Peach and nectarine fruit production in the Sandomierska Plateau in the years 2004- 2007 was risky. In 2006, damage to the flower buds during winter caused no crop yield in young peach trees and the older ones of the 'Harbinger' cultivar. A minor reaction to the temperature drop, down to $-26.8^{\circ} \mathrm{C}$, was found for nectarines in comparison with peach trees. In 2007, the spring frost injured flower pistils and caused a lack of crops from the studied cultivars.
\end{abstract}




\section{INTRODUCTION}

According to Sansavini et al. (2006), the world production of peach and nectarine fruits is continuously increasing. A special interest is being observed worldwide in the cultivars with yellow flesh. It is believed that 719 out of the 1126 peach and nectarine cultivars cultivated in different countries are characterized by yellow flesh.

Poland produces about 10 thousand tons of peaches and nectarines yearly, and the country also imports 65 thousand tons of these fruits. Makosz (2007) believes that establishing a new commercial peach and nectarine orchard in the regions with favourable climate conditions in Lower Silesia and Sandomierska Plateau seems to be very important for farmers, national marketing and consumers.

The region of the Sandomierska Plateau is characterized by a milder climate than the neighbouring regions. Apricot trees have been cultivated in commercial orchards here for a number of years. Successes in growing this species have encouraged farmers to grow species that are more sensitive to frost, like peaches and nectarines.

A number of authors (Zaliwski 1984, Radajewska et al. 1987, Hołubowicz and Bojar 1998, Szewczuk et al. 1998, Andrzejewska and Radajewska 1999, 2000, Szewczuk 2000, Jakubowski 1998, 2000) drew attention to the sizable risk of commercial peach cultivation in Polish conditions due to potential harm to flowers and trees caused by low temperatures. According to the researchers mentioned above, a proper site and cultivar selection are important limiting factors.

The aim of this experiment was to compare the performance of peach and nectarine cultivars growing in the conditions of the Sandomierska Plateau.

\section{MATERIAL AND METHODS}

The investigation was conducted in the years $2004-2007$ in a commercial orchard belonging to Mr. and Mrs. Juda at Lojowice, Samborzec commune, Sandomierska Plateau. In the spring of 1999 and 2002, peach trees from four cultivars budded on peach seedling rootstock were planted at a spacing of $4 \times 2.5 \mathrm{~m}$ apart in grey brown podzolic soil.

The experiments were established in completely randomised blocks including two or four cultivars in five replications each consisting of three trees. The treatments were 'Inka' and 'Harbinger' peaches from trees planted in 2002, and 'Inka' and Harbinger' peach trees and 'John Rivers' and 'Harko' nectarine trees planted in 1999.

During the three years of the experiment, trunk diameter (at the height of 30 $\mathrm{cm}$ ), and width and height of the canopy were measured. The fruit yield from each 
tree was weighed. Tree measurements were then used to calculate trunk crosssectional area, canopy volume and tree trunk and canopy efficiency.

In 2004, investigations were performed to determine flowering and harvesting times. In that year, during the harvest, 100 fruits from each tree were weighed.

The data were subjected to analysis of variance and Tukey's confidence intervals at a level of significance of $p=0.05$.

\section{RESULTS AND DISCUSSION}

In 2004, the earliest blooming time was shown for 'Harbinger' trees. The trees reached full blooming after 3-4 days. In younger trees the full bloom took place 1-2 days later. The length of the blooming period, depending on the cultivar, ranged from six to nine days (Table 1).

Table 1. Blooming time and harvest time of peach and nectarine cultivars in 2004

\begin{tabular}{lcccc}
\hline Cultivars & \multicolumn{3}{c}{ Data of blooming period } & Harvest time \\
\cline { 2 - 4 } & $\begin{array}{c}\text { Blooming } \\
\text { period }\end{array}$ & Full blooming & $\begin{array}{c}\text { Length of } \\
\text { blooming (days) }\end{array}$ & \\
\hline 'Harbinger' & $14-22$ Apr. & 17 Apr. & 9 & $12-18$ Aug. \\
'Inka' & $19-26$ Apr. & $22 \mathrm{Apr}$. & 8 & $21-28$ Aug. \\
'John Rivers' & $19-26$ Apr. & 22 Apr. & 8 & $24-30$ Aug. \\
'Harko' & $19-24$ Apr. & 21 Apr. & 6 & $14-30$ Aug. \\
\hline
\end{tabular}

Table 2. Tree vegetative growth of peach and nectarine cultivars in 2004- 2006

\begin{tabular}{|c|c|c|c|c|c|c|}
\hline \multirow[t]{2}{*}{ Cultivars } & \multicolumn{2}{|c|}{$\begin{array}{c}\text { Trunk cross sectional } \\
\text { area } \\
\left(\mathrm{cm}^{2}\right)\end{array}$} & \multirow{2}{*}{$\begin{array}{c}\text { TCSA } \\
\text { in } 2006 \\
\text { in comparison to } \\
2004(\%)\end{array}$} & \multicolumn{2}{|c|}{$\begin{array}{l}\text { Canopy } \\
\text { volume } \\
\left(\mathrm{m}^{3}\right)\end{array}$} & \multirow{2}{*}{$\begin{array}{l}\text { Canopy volume } \\
\text { in } 2006 \\
\text { in comparison to } \\
2004(\%)\end{array}$} \\
\hline & 2004 & 2006 & & 2004 & 2006 & \\
\hline \multicolumn{7}{|c|}{ Trees planted in 2002} \\
\hline 'Harbinger' & $22.0 \mathrm{a}^{*}$ & 65.8 & 299 & $1.8 \mathrm{a}$ & 5.8 & 322 \\
\hline 'Inka' & $13.9 \mathrm{~b}$ & 58.6 & 421 & $1.0 \mathrm{~b}$ & 4.9 & 490 \\
\hline $\mathrm{LSD}_{0.05}$ & 2.8 & n.s. & & 0.4 & n.s. & \\
\hline \multicolumn{7}{|c|}{ Trees planted in 1999} \\
\hline 'Harbinger' & $107.1 \mathrm{a}$ & $193.5 \mathrm{a}$ & 180 & $8.3 \mathrm{a}$ & 12.9 & 155 \\
\hline 'Inka' & $88.3 \mathrm{bc}$ & $198.4 \mathrm{a}$ & 225 & $6.0 \mathrm{~b}$ & 10.1 & 170 \\
\hline 'John Rivers' & $93.0 \mathrm{ab}$ & $173.7 \mathrm{a}$ & 187 & $6.7 \mathrm{~b}$ & 10.7 & 160 \\
\hline ‘Harko’' & $73.3 \mathrm{c}$ & $124.4 \mathrm{a}$ & 170 & $5.2 \mathrm{~b}$ & 8.3 & 160 \\
\hline $\mathrm{LSD}_{0.05}$ & 18.4 & 83.2 & & 1.5 & n.s. & \\
\hline
\end{tabular}

*means followed by the same letter do not significantly differ at $\mathrm{p}=0.05$ 
Table 3. Yielding and fruit quality of peach and nectarine in $2004-2006$

\begin{tabular}{|c|c|c|c|c|c|c|c|c|}
\hline \multirow[t]{2}{*}{ Cultivars } & \multicolumn{4}{|c|}{ Yield $\left(\mathrm{kg}\right.$ tree $\left.^{-1}\right)$} & \multicolumn{3}{|c|}{$\begin{array}{l}\text { Comparison between the } \\
\text { years }\end{array}$} & \multirow[t]{2}{*}{ Fruit weight (g) } \\
\hline & 2004 & 2005 & 2006 & Mean & 2004 & 2005 & 2006 & \\
\hline \multicolumn{9}{|c|}{ Trees planted in 2002} \\
\hline 'Harbinger' & 9.6 & $16.2 \mathrm{~b}$ & 0.0 & 8.6 & B & A & $\mathrm{C}$ & $100 \mathrm{~b}$ \\
\hline 'Inka' & 8.3 & $19.5 \mathrm{a}$ & 0.0 & 9.3 & B & A & $\mathrm{C}$ & $150 \mathrm{a}$ \\
\hline $\mathrm{LSD}_{0.05}$ & n.s. & 1.8 & n.s. & & & & & 7.3 \\
\hline \multicolumn{9}{|c|}{ Trees planted in 1999} \\
\hline 'Harbinger' & $28.6 \mathrm{~b}$ & $33.9 \mathrm{a}$ & $0.0 \mathrm{~d}$ & 20.8 & B & A & $\mathrm{C}$ & $70 \mathrm{~b}$ \\
\hline 'Inka' & $34.0 \mathrm{a}$ & $29.9 \mathrm{~b}$ & $4.0 \mathrm{c}$ & 22.6 & A & B & $\mathrm{C}$ & $89 a$ \\
\hline 'John Rivers' & $34.0 \mathrm{a}$ & $29.0 \mathrm{~b}$ & $10.5 \mathrm{~b}$ & 24.5 & A & A & B & $47 \mathrm{c}$ \\
\hline 'Harko’' & $31.4 \mathrm{ab}$ & $28.6 \mathrm{~b}$ & $19.8 \mathrm{a}$ & 26.6 & A & A & $\mathrm{B}$ & $49 \mathrm{c}$ \\
\hline $\operatorname{LSD}_{0.05}$ & 5.3 & 3.7 & 1.9 & & & & & 7.4 \\
\hline
\end{tabular}

Explanation: see Table 2

Table 4. Yield efficiency of peach and nectarine in $2004-2006$

\begin{tabular}{|c|c|c|c|c|c|c|}
\hline \multirow[t]{3}{*}{ Cultivars } & \multicolumn{6}{|c|}{ Yield efficiency of: } \\
\hline & \multicolumn{3}{|c|}{$\operatorname{TCSA}\left(\mathrm{kg} \mathrm{cm}^{-2}\right)$} & \multicolumn{3}{|c|}{ Canopy volume $\left(\mathrm{kg} \mathrm{m}^{-3}\right)$} \\
\hline & 2004 & 2005 & 2006 & 2004 & 2005 & 2006 \\
\hline \multicolumn{7}{|c|}{ Trees planted in 2002} \\
\hline 'Harbinger' & 0.3 & $0.40 \mathrm{~b}$ & 0.0 & 2.3 & $2.8 \mathrm{~b}$ & 0.0 \\
\hline 'Inka' & 0.4 & $0.54 \mathrm{a}$ & 0.0 & 2.8 & $4.5 \mathrm{a}$ & 0.0 \\
\hline $\mathrm{LSD}_{0.05}$ & n.s. & 0.09 & - & n.s. & 1.0 & - \\
\hline \multicolumn{7}{|c|}{ Trees planted in 1999} \\
\hline 'Harbinger' & $0.24 \mathrm{~b}$ & 0.20 & 0.0 & $2.3 \mathrm{c}$ & 2.7 & $0.0 \mathrm{c}$ \\
\hline 'Inka' & $0.34 \mathrm{ab}$ & 0.30 & 0.02 & $3.8 \mathrm{~b}$ & 4.0 & $0.4 \mathrm{c}$ \\
\hline 'John Rivers' & $0.30 \mathrm{ab}$ & 0.20 & 0.10 & $3.4 \mathrm{~b}$ & 3.1 & $1.7 \mathrm{~b}$ \\
\hline 'Harko' & $0.36 \mathrm{a}$ & 0.30 & 0.18 & $5.1 \mathrm{a}$ & 4.1 & $2.6 \mathrm{a}$ \\
\hline $\mathrm{LSD}_{0.05}$ & 0.11 & n.s. & n.s. & 1.1 & n.s. & 0.9 \\
\hline
\end{tabular}

Explanation: see Table 2

'Harbinger' and 'Harko' fruits were harvested the earliest (12, 14 August), while the fruits of the other cultivars were harvested 9-12 days later. The 'Harko' cultivar was characterized by a very uneven ripening, and the fruits of this cultivar were harvested three times. The harvest of other cultivars was also performed twice due to the purpose the fruits were intended for. In other years, which featured much higher temperatures in spring and July, the harvest of fruits took place 4-7 days earlier. Similar differences in the times of blooming and harvesting were observed by Jakubowski $(1998,2000)$, whereas Szewczuk et al. (1998) reported much earlier harvesting times for Lower Silesia. 
In trees planted in 2002, the trees of the 'Harbinger' cultivar were larger than the trees of the 'Inka' cultivar. Both the trunk cross sectional area and the canopy volume did show significant differences between the cultivars only in 2004 .

In 2004 older trees of the 'Harbinger' cultivar had significantly thicker trunks and bigger canopy volumes compared to 'Inka'. In the last year of investigations the differences in tree size between those cultivars were insignificant. When comparing nectarine cultivars, in 2004 the 'John Rivers' trees had significantly thicker trunks and bigger canopy volume than 'Harko'.

The younger peach trees experienced a much faster increase in trunk thickness and canopy volume than the trees planted in 1999. Szewczuk (1999) reported a similar growth of 'Inka' trees. He drew attention to the fact that the manner of soil cultivation can considerably change the intensity of growth of young peach trees.

The peach trees began yielding crops very early. More than $8 \mathrm{~kg}$ of fruits were picked up from the young trees in the third year after planting. Only in 2005 there were significant differences between the cultivars in the group of trees planted in 2002. Szewczuk (2000) found a similar precocity of cropping for peach trees but saw slightly higher yields in the vicinity of Wrocław. The group of trees planted in 1999 produced a high mean yield of 20.8-26.6 kg per tree. In 2004 and 2006 'Inka' peach trees provided a significantly higher yield than 'Harbinger'. On the other hand, in 2005 significantly more fruits were harvested from 'Harbinger' trees than from 'Inka'.

In nectarine trees, no significant differences between the cultivars in 2004 and 2005 were found. In 2006 'Harko' was characterized by a significantly higher yield than 'John Rivers'. Earlier studies by Szewczuk (2000) also showed large differences among the cultivars. This author obtained much higher yields from trees planted at greater spacing.

Significant differences in yielding were shown between the years of the experiment. In all of the tested cultivars, significantly fewer fruits were harvested in 2006 than in the remaining years. The very strong freezing of flower buds during a cold winter in $2005-2006$, when the temperature dropped down to $-26.8^{\circ} \mathrm{C}$ (23 Jan.), caused a lack of crops from the young peach trees and older 'Harbinger' trees. 'Inka' trees gave seven times lower yields in comparison with other years.

Relatively high yields were harvested from nectarine trees. Damage to the canopies and the die-back of the upper parts of the strongest one-year-old shoots were observed in all of the studied cultivars. The trees regenerated very well during the next vegetation period and we did not observe deaths of whole trees. Strong spring frosts, which occurred at the turn of April and May 2007, damaged the flowers, thus eliminating crops from the examined cultivars. Similar frost damage in the Wielkopolska region after the winter of 1986 - 1987 was found by Radajewska et al. (1987). These authors' views on the peach trees' successful recovery from frost damage was confirmed in the studied conditions. However, 
a chance to obtain high peach and nectarine yields in the region of Sandomierz in the studied period was not very high. For instance, in the period of four years of studies we observed one year with no crops due to flower damage by spring frosts, and another year of poor cropping caused by a frosty winter. The present study confirmed the view, widely known in the literature, that growing peaches and nectarines in Poland's climate conditions is extremely risky (Zaliwski 1984, Radajewska et al. 1987, Hołubowicz and Bojar 1998, Andrzejewska and Radajewska 1999, 2000, Jakubowski 2000, Szewczuk 2000).

In both age groups, the 'Inka' cultivar produced significantly larger fruits than 'Harbinger'. The studied nectarine cultivars did not significantly differ in fruit size, and they produced much smaller fruits than peaches. In order to obtain good quality fruits it is necessary to thin fruitlets, especially in the case of the examined nectarines. De Jong (2006) believes that the period of the first 30 days after peach blooming is decisive of the final size of the fruits, and it is the only period when is possible to positively influence fruit size by thinning.

In the group of trees planted in 2002, 'Inka' showed to have significant greater tree trunk efficiency in the year 2005 than 'Harbinger'. A similar regularity was found for canopy efficiency.

The tree trunks and canopies of older 'Inka' trees were characterized by higher efficiency than 'Harbinger' trees. The differences between those cultivars were significant only for canopy efficiency in 2004 . The present studies confirmed the views of Jakubowski (2000) and Szewczuk (2000) on the considerable usefulness of 'Inka' for planting in the warmer regions of Poland.

'Harko' nectarine canopies were significantly more productive than those of 'John Rivers' in the years 2004 and 2006.

\section{CONCLUSIONS}

1. The studied peach and nectarine cultivars differed in the strength of their tree growth. The trunks and canopies of young trees increased about twice as fast as older ones.

2. In the conditions of the Sandomierska Plateau, the study found significant differences in crop yield between the different years of each cultivar. Strong frost damage in 2006 caused a lack of cropping by older 'Harbinger' trees and younger ones of both peach cultivars. Nectarine trees cropped much better in that year.

3. Peach and nectarine cultivation in the Sandomierska Plateau can produce high yields. Low temperatures in winter and spring frost cause a high risk of reduced or no yields. 'Inka' and 'Harko' are the most useful cultivars for the studied region due to a high possibility of cropping and efficiency of trees. It is 
necessary to thin out the fruit in order to improve its quality, especially in the case of the 'Harko' cultivar.

\section{REFERENCES}

ANDRZEJEWSKA L., RADAJEWSKA B., 1999. Wartość produkcyjna 11 nowych odmian brzoskwini i nektaryny. Roczn. AR Poznań, Ogrodn. 28: 3-10.

ANDRZEJEWSKA L., RADAJEWSKA B., 2000. Brzoskwinie i nektaryny w uprawie pod osłonami cz. I i II. Prace Kom. Nauk Roln. Leśn. PTPN 89: 107-117.

DE JONG T.M., 2006. Physiological and developmental principles of peach tree and fruit growth related to menagement practices. Acta Hort. 713: 163-167.

HOŁUBOWICZ T., BOJAR K., 1998. Wpływ podkładki na wzrost, plonowanie i mrozoodporność brzoskwini odmiany Reliance. Zesz. Nauk. AR Kraków 333, 57: 435-438.

JAKUBOWSKI T., 1998. Wstępna ocena odmian brzoskwiń w nasadzeniach kolekcyjnych. Mat. Konf. Brzoskwiniowej ISK, Skierniewice: 7-10.

JAKUBOWSKI T., 2000. Uprawa brzoskwini i nektaryny. Hortpress sp. z o.o. Warszawa.

MAKOSZ E., 2007. Szanse rozwoju polskiego sadownictwa. Plantpress sp. z o.o., Kraków.

RADAJEWSKA B., ZGOŁA K., DUDZIŃSKI F., 1987. Wielkopolskie brzoskwinie po zimie 1986/1987. Prace ISK, Skierniewice, Seria C, 1-4: 38-40.

SANSAVINI S., GAMBERINI A., BASSI D., 2006. Peach breeding, genetics and new cultivar trends. Acta Hort. 713: 23-48.

SZEWCZUK A., 1999. Plonowanie i wzrost młodych drzew brzoskwini w zależności od sposobu uprawy gleby w rzędach drzew. Zesz. Nauk. AR Kraków 351, 66: 305-308.

SZEWCZUK A., GUdAROWSKA E., LinCZAR-MALAŃCZUK H., 1998. Ocena przydatności niektórych odmian brzoskwini do nasadzeń towarowych w warunkach Dolnego Śląska. Zesz. Nauk. AR Kraków 333, 57: 607-611.

SZEWCZUK A., 2000. Przegląd wyników doświadczeń prowadzonych w Akademii Rolniczej we Wrocławiu nad unowocześnianiem technologii uprawy brzoskwini. XX Międzynar. Sem. Sadown. w Limanowej: 121-126.

ZALIWSKI S., 1984. Intensywna uprawa drzew ziarnkowych i pestkowych. PWN, Warszawa. 


\section{WZROST I OWOCOWANIE DWÓCH ODMIAN BRZOSKWINI I NEKTARYNY NA WYŻYNIE SANDOMIERSKIEJ}

Streszczenie: Oceniane odmiany brzoskwini i nektaryny różniły się siłą wzrostu. Wśród brzoskwiń drzewa odmiany 'Inka' rosły słabiej niż odmiana 'Harbinger'. Nektaryna 'John Rivers' charakteryzowała się silniejszym wzrostem niż 'Harko'. Plonowanie drzew zależało od odmiany i warunków meteorologicznych w okresie zimy i wiosny. Wyższe plony i bardziej okazałe owoce tworzyła odmiana 'Inka' niż 'Harbinger'. Tylko w 2006 roku odmiana 'Harko' dała istotnie wyższy plon niż 'John Rivers'. Produkcja owoców brzoskwini i nektaryny na Wyżynie Sandomierskiej w latach 2004 - 2007 była bardzo ryzykowna. W 2006 roku uszkodzenia pąków kwiatowych w okresie zimy spowodowały brak owocowania młodych drzew brzoskwini i starszych odmiany 'Harbinger'. U nektaryn zanotowano mniejszą reakcję na spadek temperatury do $-26,8^{\circ} \mathrm{C}$. W 2007 roku przymrozki wiosenne uszkodziły słupki w kwiatach i spowodowały brak plonowania wszystkich odmian. 